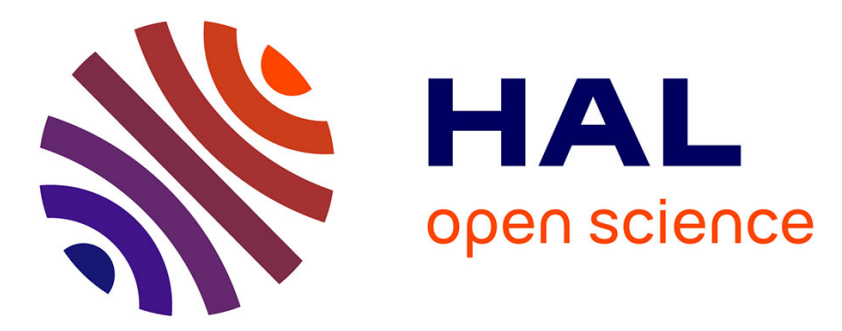

\title{
Textural and hydration properties of a synthetic montmorillonite compared with a natural Na-exchanged clay analogue.
}

Lydie Le Forestier, Fabrice Muller, Frédéric Villiéras, Manuel Pelletier

\section{- To cite this version:}

Lydie Le Forestier, Fabrice Muller, Frédéric Villiéras, Manuel Pelletier. Textural and hydration properties of a synthetic montmorillonite compared with a natural Na-exchanged clay analogue.. Applied Clay Science, 2010, 48, pp.18-25. 10.1016/j.clay.2009.11.038 . insu-00433524

HAL Id: insu-00433524

https://hal-insu.archives-ouvertes.fr/insu-00433524

Submitted on 21 Dec 2009

HAL is a multi-disciplinary open access archive for the deposit and dissemination of scientific research documents, whether they are published or not. The documents may come from teaching and research institutions in France or abroad, or from public or private research centers.
L'archive ouverte pluridisciplinaire $\mathbf{H A L}$, est destinée au dépôt et à la diffusion de documents scientifiques de niveau recherche, publiés ou non, émanant des établissements d'enseignement et de recherche français ou étrangers, des laboratoires publics ou privés. 
Title of the article

TEXTURAL AND HYDRATION PROPERTIES OF A SYNTHETIC

MONTMORILLONITE COMPARED WITH A NATURAL NA-EXCHANGED CLAY

ANALOGUE

Authors

Lydie LE FORESTIER $^{1 *}$, Fabrice MULLER ${ }^{1}$, Frédéric VILLIERAS ${ }^{2}$, Manuel PELLETIER ${ }^{2}$

Address

${ }^{1}$ Institut des Sciences de la Terre d’Orléans (ISTO) : UMR 6113, Université d'Orléans,

CNRS-INSU, Université François Rabelais - Tours, 1A Rue de la Férollerie, 45071 Orléans

Cedex 2, France

${ }^{2}$ Laboratoire Environnement et Minéralurgie (LEM) : UMR 7569, Nancy Université / CNRS, 15 avenue du Charmois, 54500 Vandœuvre-lès-Nancy Cedex, France

* Corresponding author:

E-mail address: lydie.leforestier@univ-orleans.fr

Telephone number: +33238255393

Fax number: +33238636488 


\section{Abstract:}

An aluminous montmorillonite has been synthesized at hydrothermal conditions (623 K, 120 $\mathrm{MPa}$ ) and compared to the natural Na-exchanged Wyoming montmorillonite (Na-SWy2). The synthetic product is characterized by a high cation exchange capacity (83 meq/100g) and ethylene glycol specific surface area $\left(764 \mathrm{~m}^{2} / \mathrm{g}\right)$ similar to Na-SWy2 but with a higher purity with one crystalline phase. Compacted smectite samples were percolated with water by using an œdometer cell equipped with a separated injection system, in order to simulate the behaviour of an engineered clay barrier in the context of subsurface waste landfill. Percolation experiments showed very low hydraulic conductivities $\left(10^{-12} \mathrm{~m} / \mathrm{s}\right)$ for both synthetic and natural smectites, in addition to the non macroscopic swelling of the synthetic montmorillonite, in contrast to Na-SWy2. At the nanometric scale, this synthetic clay mineral is characterized by higher hydration states and a better organization in the distribution of water molecules in particles, as proven by X-ray diffraction technique and continuous water vapor gravimetry method. Moreover, adsorption-desorption isotherms of nitrogen revealed the classical feature of swelling clay minerals, and the Brunauer-Emmet-Teller calculation gives a nitrogen specific area of $87 \mathrm{~m}^{2} / \mathrm{g}$ for the synthetic smectite, twice higher than for the Wyoming clay, due to its higher mesoporosity. Finally, low-pressure argon adsorption coupled with the Derivative Isotherm Simulation procedure highlighted classical adsorption energy distributions of natural phyllosilicates, and thus the synthetic montmorillonite was characterized by an average of 11 layers per particle in the dry state, with basal and edge surface areas different from Na-SWy2.

Keywords: Hydrothermal synthesis; Wyoming montmorillonite; hydraulic conductivity; swelling; $\mathrm{N}_{2} / \mathrm{Ar} /$ water adsorption 


\section{Introduction}

Bentonites are used in numerous industrial, agricultural and environmental applications (Murray, 1999), in particular, as engineered barrier for high-level nuclear waste repositories or subsurface waste disposals. These clays are of great interest due to their rather low permeability when compacted, their ability to expand and their capacity to retain pollutants. Bentonites take advantage of the hydration, swelling, cation exchange, and surface complexation capacity of montmorillonite, its main mineral component (Caglar et al., 2009). Bentonites, being natural materials, contain impurities and different clay minerals, and their intrinsic features may induce chemical and mineralogical variations (Galan, 2006). On the contrary, synthetic clay minerals are reproducible and homogeneous in terms of the chemical composition, mineralogy, texture, and thus, they become useful for systematic studies aimed at a better understanding of the interaction mechanisms between clay minerals and metal ions or organic pollutants. Before considering synthetic smectites as a suitable model of natural bentonites, it is necessary to elucidate their basic characteristics such as cation exchange capacity, surface properties, morphology, and in particular their behaviour at different scales when contacted with water. Indeed, smectites are characterized at the nanometric scale by a crystalline swelling in that water molecules can be intercalated between individual 2:1 layers (0 to 4 water layers), and also by a macroscopic swelling. At the macroscopic scale, the measured swelling of smectites results from a combination of several simultaneous processes: crystalline swelling, double-layer swelling, breakup of crystals, cation demixing, co-volume swelling, and Brownian swelling (Laird, 2006).

Although dioctahedral smectites, such as montmorillonites, are predominant in soils and sediments and they are widely used in many industrial applications, most of the clay studies have been devoted to the synthesis of trioctahedral smectites, such as hectorite 
(Carrado et al., 1997; Spagnuolo et al., 2004), and saponite (Delevoye et al., 2003).

Beidellites (Kloprogge et al., 1993; Lantenois et al., 2008a) and nontronites (Decarreau et al., 2008) have been synthesized as dioctahedral smectites, but the synthesis of montmorillonite in high purity is rarely achieved due to the difficulty to achieve it (Reinholdt et al., 2005; Lantenois et al., 2008b).

Therefore, in the present study we focus on the comparison of textural, cation exchange, hydration and swelling properties of a synthetic montmorillonite with those of the sodium-exchanged Wyoming smectite which is considered as its natural clay analogue.

\section{Materials and methods}

\subsection{Starting materials}

\subsubsection{Natural clay}

The natural clay used for this study is the SWy-2 Wyoming montmorillonite supplied by the Source Clay Minerals Repository of the Clay Minerals Society. The impurities identified as quartz, feldspar, gypsum, mica, illite in the SWy-2 sample represent $5 \%$ after purification by $<2 \mu \mathrm{m}$ size separation (Chipera and Bish, 2001). The SWy-2 montmorillonite was sodium-saturated by exchange in $1 \mathrm{M} \mathrm{NaCl} .2 \mathrm{~g}$ of SWy-2 and $50 \mathrm{~mL}$ of $1 \mathrm{M} \mathrm{NaCl}$ solution were mixed on a SRT1 Stuart Scientific roller mixer for $16 \mathrm{~h}$, and then the mixture was centrifuged. The supernatant chloride solution was filtered off and the tube was refilled with the $1 \mathrm{M} \mathrm{NaCl}$ solution. This exchange procedure was repeated five times. The sample was then transferred into a dialysis membrane tubing and placed in deionised water to remove chlorine. The water was daily refreshed until the disappearance of chlorine ( $\mathrm{AgNO}_{3}$ test). After dialysis and decantation, the $<2 \mu \mathrm{m}$ fraction of Na-SWy2 samples was recovered, dried 
and finely hand ground in an agate mortar. Electron microprobe analyses using a CAMECA SX50 electron microprobe (EMPA) operating at $15 \mathrm{kV}$ accelerating voltage and $6 \mathrm{nA}$ intensity, as well as ICP-OES analysis were carried out to quantify the structural formula of the $<2 \mu \mathrm{m}$ Na-exchanged SWy-2, called afterwards Na-SWy2 (Table 1). The structural formula of this clay mineral is close to that previously determined by Michot et al. (2004).

\subsubsection{Synthetic smectite}

The starting material for the hydrothermal syntheses was a gel of anhydrous composition $0.33 \mathrm{Na}_{2} \mathrm{O}-1.67 \mathrm{Al}_{2} \mathrm{O}_{3}-0.66 \mathrm{MgO}-8 \mathrm{SiO}_{2}$ and prepared using a procedure adapted from Hamilton and Henderson (1968), and Lantenois et al. (2008b). The chemicals for the gel preparation, with a 99\% minimum grade purity, were $\mathrm{Na}_{2} \mathrm{CO}_{3}$ (Prolabo, $0.5 \mathrm{~g} / 10 \mathrm{~g}$ dry gel), tetraethylorthosilicate (TEOS, Fluka, $23.87 \mathrm{~g} / 10 \mathrm{~g}$ dry gel) as the silicon source, solutions of $\mathrm{Al}\left(\mathrm{NO}_{3}\right)_{3} .9 \mathrm{H}_{2} \mathrm{O}(27.53 \mathrm{~g} / 10 \mathrm{~g}$ dry gel $)$ and $\mathrm{Mg}\left(\mathrm{NO}_{3}\right)_{2} \cdot 6 \mathrm{H}_{2} \mathrm{O}(3.72 \mathrm{~g} / 10 \mathrm{~g}$ dry gel $)$, whose titration is $88.6 \mathrm{mg} \mathrm{Al}_{2} \mathrm{O}_{3} / \mathrm{g}$ and $102.5 \mathrm{mg} \mathrm{MgO} / \mathrm{g}$ respectively, $\mathrm{NH}_{4} \mathrm{OH}$ (Aldrich), and ethanol (Aldrich, $30 \mathrm{~mL} / 10 \mathrm{~g}$ dry gel), were used as solvent. After the dissolution of sodium carbonate in Mg- and Al-nitrate solution ( $\mathrm{pH}=2)$, TEOS and ethanol are added. $\mathrm{NH}_{4} \mathrm{OH}$ is added up to the formation of a precipitate. After the complete hydrolysis of the TEOS (16 h), the precipitate is progressively heated up to $873 \mathrm{~K}$ to remove water, organic matter, $\mathrm{NO}_{2}$, and $\mathrm{CO}_{2}$, and to obtain a Na-Mg-Al-Si oxide gel. This gel is finally ground in an agate mortar.

Experimental charges were prepared as following: deionised water and gel (weight ratio 1:5) were placed into a gold capsule welded on one end. The capsule was closed by arcwelding, while its main body was constantly cooled in liquid nitrogen. Hydrothermal syntheses were carried out in Tuttle-type, externally heated, cold-seal pressure vessels, using argon as the pressure medium at $623 \mathrm{~K}$ and $120 \mathrm{MPa}$, for the duration of 28 days. All capsules were leak-checked before the start of the experiment (test with oil), and after by reweighing. 


\subsection{Percolation experiments}

Percolation experiments have been performed using œdometer cells equipped with a separated injection system characterized by a controlled mechanical pressure. This specific equipment has been developed, in order to mimic the subsurface landfill conditions at laboratory scale (Jullien and Lecomte, 2000; Jullien et al., 2002). The œdometer cell, used in this study, is characterized by a $10 \mathrm{~mm}$ diameter, which requires low sample masses (ca. 400 mg for each experiment), and so adapted for synthetic clay minerals. Besides, this cell is equipped with a piston for mechanical stress control. The axial displacements of the piston are measured with a dial indicator of a $0.5 \mu \mathrm{m}$ precision. Porous sintered bronze plates surrounded by teflon waterproof rings are used at the top and bottom of the cell. The porous plates are covered with filter paper to prevent pore obstruction by the clay sample. Concerning solute injection, the syringe, made of inert materials, allows to apply a constant mechanical pressure to the solution with a piston. The syringe piston displacements, which can be related to the injected volume, are picked up from a dial indicator. Negligible strains of the syringe are obtained in the range of applied injection pressures (below $1 \mathrm{MPa}$ ). Therefore, the injection pressure is separately controlled from the mechanical pressure applied to the clay sample based upon the experimental parameters optimized to reproduce the hydro-mechanical conditions of subsurface landfill well (Pothier et al., 2003). So, for each experiment, the airdried smectite sample is firstly compacted up to $0.5 \mathrm{MPa}$ and totally unloaded, in order to simulate the over-consolidation of engineered clay barriers. Then, deionised water is injected into the compacted clay sample under a constant pressure of $0.3 \mathrm{MPa}$, applied to the upper boundary while the lower boundary is exposed to a mechanical stress of $0.3 \mathrm{MPa}$. Such test conditions lead to an over-consolidation ratio of 1.66. The sample thickness and the injected volume were monitored during testing, as well as the weight of the possible output solutions. 
At the end of each experiment, the clay sample was removed, and the final mass and thickness were measured.

\subsection{Hydration experiments}

\subsection{1. $X$-ray diffraction}

Structural investigation of the clay minerals, as well as the study of the hydration properties, was carried out using X-ray diffraction (XRD) technique. XRD patterns were recorded using a Thermo Electron ARL'XTRA diffractometer equipped with a Cu anode and a Si(Li) solid detector. The vertical $\theta: \theta$ goniometer supports two Sollers slits. A VTI RH 200 relative humidity generator device coupled with an Anton Paar THC chamber allows to select variable environmental conditions. Experimental measurement parameters were 10 s counting time per $0.05^{\circ} 2 \theta$ step. The divergence, the incident beam scatter, the diffracted beam scatter and the receiving slits are 1.0, 1.5, 0.45 and $0.30 \mathrm{~mm}$, respectively. 30-60 mg of powder sample is necessary for XRD analysis. Data collection was performed at $303 \mathrm{~K}$ and 50\% relative humidity (RH) after establishing an equilibrium period of $1 \mathrm{~h}$ prior to the measurement. Concerning hydration, the first step, at 5\% RH, was obtained after an equilibrium period of $24 \mathrm{~h}$ before the pattern was recorded. Then the sample was gradually hydrated from 5 to $99 \% \mathrm{RH}$ for 1 h of equilibrium period before measurement.

\subsubsection{Quasi-equilibrium water vapor adsorption-desorption}

Water vapor adsorption-desorption measurements were carried out in a continuous gravimetric apparatus built around a Setaram MTB 10-8 symmetric microbalance with a precision of $1 \mu \mathrm{g}$ (Cases et al., 1992). $43 \mathrm{mg}$ of Na-MMT sample was outgassed overnight under vacuum $(0.01 \mathrm{~Pa})$ at $383 \mathrm{~K}$ before the measurement. The sample was exposed to water 
vapor was supplied to the sample through an Edwards microleak valve, at a constant slow flow rate to maintain quasi-equilibrium conditions during the experiment. Water pressure is measured by a DRUCK 0-13333 Pa absolute pressure sensor. The adsorption-desorption isotherm, that is the plot of the mass of $\mathrm{H}_{2} \mathrm{O}$ adsorbed or desorbed at $303 \mathrm{~K}$ versus pressure, was directly recorded on a computer. Experimental data were further analyzed using the BET equation. Specific surface areas were calculated referring to the two cross-sectional area values of the adsorbed water molecules, 0.106 and $0.148 \mathrm{~nm}^{2}$, corresponding to various packings of liquid water on mineral surfaces (Harkins and Jura, 1944; Cases et al., 1992).

\subsection{Complementary characterization}

\subsubsection{CEC measurements}

The Cation Exchange Capacity (CEC) values of Na-SWy2 and Na-MMT were measured using the copper complex method (Ammann et al., 2005), for which $100 \mathrm{mg}$ of dry clay sample was suspended in $8 \mathrm{~mL}$ of $0.01 \mathrm{M}$ copper triethylenetetramine ([Cu(trien) $\left.]^{2+}\right)$ solution. The solution was shaken for $15 \mathrm{~h}$ and then centrifuged at $6000 \mathrm{rpm}$ for $15 \mathrm{~min}$. The $\mathrm{Cu}$ concentration of each supernatant was measured (i) by colorimetry using a Hitachi U-1100 spectrophotometer, at $577 \mathrm{~nm}$, and also (ii) by atomic absorption spectrometry (AAS) using a Hitachi Z-8100 spectrophotometer.

\subsubsection{Specific surface area}

The specific surface areas of Na-SWy2 and Na-MMT, representing the complete unimolecular surface coverage of montmorillonite by ethylene glycol, were experimentally determined (Eltantawy and Arnold, 1974). 


\subsection{3. $N_{2}$ adsorption}

The nitrogen adsorption-desorption volumetry at 77K was performed using a lab-built automatic apparatus described by Marrochi et al. (2005). $1 \mathrm{~g}$ of sample was outgassed at 383 K under a residual pressure of 0.01 Pa. Specific surface area was determined using the BET equation (Brunauer et al., 1938) based upon the cross-sectional area of nitrogen $\left(0.163 \mathrm{~nm}^{2}\right)$ at 77K (Sing et al., 1985). The presence of micropores in the sample was assessed using the tplot method (De Boer et al., 1966). Pore size distributions were calculated following the BJH method (Barrett et al., 1951).

\subsubsection{Ar adsorption}

High-resolution low-pressure argon adsorption was carried out on an automatic quasiequilibrium volumetric set-up (Michot et al., 1990, Villiéras et al., 1992, 1997a). 1 g of sample was outgassed overnight at $383 \mathrm{~K}$ under a residual pressure of $10^{-4} \mathrm{~Pa}$. After outgassing, a slow, constant and continuous flow of argon was introduced into the adsorption cell through a microleak. The adsorption isotherms were then derived from the recording of quasi-equilibrium pressures versus time. The data were then treated using the Derivative Isotherm Simulation (DIS) procedure designed by Villiéras et al. (1992, 1997a, 1997b) to examine the surface energetic heterogeneity of the Na-MMT sample. Having the large number of experimental data points acquired by the quasi-equilibrium technique, the experimental derivative of the adsorbed amount as a function of the logarithm of relative pressure could be calculated accurately. The total derivative adsorption isotherm on a heterogeneous surface is simulated by the sum of local theoretical derivative adsorption isotherms on heterogeneous surfaces (Michot and Villiéras, 2002; Tournassat et al., 2003; Perronnet et al., 2007). 


\section{Results and discussion}

\subsection{Similar characteristics}

$\mathrm{X}$-ray diffraction patterns revealed that smectite mineral is the only crystalline phase existing in Na-MMT sample (Fig. 1). This phase was clearly identified by (00l) reflections at 5.7 $(1.55 \mathrm{~nm}), 17.4^{\circ}(0.508 \mathrm{~nm}), 28.75^{\circ}(0.31 \mathrm{~nm})$, and (02.11), (20.13), (06.33) reflections with the maxima at $19.8^{\circ}(0.448 \mathrm{~nm}), 35.3^{\circ}(0.254 \mathrm{~nm}), 62.05^{\circ}(0.149 \mathrm{~nm})$, respectively. The position of the (06.33) reflection at $0.149 \mathrm{~nm}$ confirms the predominance of dioctahedral domains in the octahedral sheets of the synthetic Na-MMT smectite similar to the natural NaSWy2 smectite. The (02.11), (20.13) reflections and the (002) and (004) reflections are also located at the same positions with those of Na-SWy2. Quartz and pyroxene were also identified in the Na-SWy2 sample. This natural bentonite still contains accessory phases despite the purification, while the synthetic Na-MMT smectite reserves the main advantage of being pure. Besides, the synthesis of montmorillonite is reproducible since ten syntheses of Na-MMT samples have been successfully performed.

As expected, the Na-SWy2 sample develops a high exchange capacity of $85 \mathrm{meq} / 100 \mathrm{~g}$ (Table 1) in agreement with the previous value obtained by Duc et al. (2006). The CEC value of the synthetic Na-MMT sample which is 83 meq/100g also confirms the high potential of exchange capacity.

The synthesized product, called Na-MMT, has the theoretical structural formulae: $\mathrm{Na}_{0.66}\left(\mathrm{Al}_{3.34} \mathrm{Mg}_{0.66}\right)\left(\mathrm{Si}_{8}\right) \mathrm{O}_{20}(\mathrm{OH})_{4} \cdot \mathrm{nH}_{2} \mathrm{O}$. The chemical analysis using ICP-OES coupled with electron microprobe analyses reveals that the charge deficit is mainly located in the octahedral sheets (Table 1), as previously shown by Lantenois et al. (2008b) for a similar synthetic smectite represented by $\mathrm{SM}_{0.33}-1200$. However, the structural formula of the $\mathrm{SM}_{0.33}-1200$ sample which was derived by Lantenois et al. (2008b) as 
$\mathrm{Na}_{0.68}\left(\mathrm{Al}_{3.32} \mathrm{Mg}_{0.72}\right)\left(\mathrm{Si}_{7.94} \mathrm{Al}_{0.06}\right) \mathrm{O}_{20}(\mathrm{OH})_{4}$ highlights the non-equilibrium between the interlayer charge $(0.68$ per unit cell $)$ and the total charge deficit $(0.72+0.06=0.78)$. Thus, it may be deduced from these data that $\mathrm{Na}^{+}$is not the only cation involved in the interlayer charge. To elaborate this, all the constituent elements ( $\mathrm{Na}, \mathrm{Al}, \mathrm{Mg}, \mathrm{Si}$ ) of the synthetic NaMMT sample were measured in the supernatant by AAS after the exchange of Na-MMT with the copper complex for the CEC determination. Magnesium may have been located in the interlayer spacing of the mineral since a minor fraction of this element is exchangeable. This allowed us to accurately calculate the structural formulae of Na-MMT as $\left(\mathrm{Na}_{0.68} \mathrm{Mg}_{0.03}\right)\left(\mathrm{Al}_{3.35} \mathrm{Mg}_{0.65}\right)\left(\mathrm{Si}_{7.91} \mathrm{Al}_{0.09}\right) \mathrm{O}_{20}(\mathrm{OH})_{4}$

The specific surface area measured by the adsorption of ethylene glycol represents the total surface area of individual sheets of the clay sample. The ethylene glycol specific surface areas of the synthetic Na-MMT and the natural Na-SWy2 montmorillonites are close to each

other (Table 1) and are in agreement with expected values of swollen clay minerals changing in the range of $700-800 \mathrm{~m}^{2} / \mathrm{g}$ (Helmy et al., 1999). The specific surface area (S) can be estimated by assuming a perfect crystal structure and ignoring the layer thickness via the equation:

$S=\left(\mathrm{N}_{\mathrm{a}} \cdot \mathrm{a} \cdot \mathrm{b} \cdot 2 \cdot 10^{-20}\right) / \mathrm{M}$

where $\mathrm{N}_{\mathrm{a}}$ is the Avogadro number, $\mathrm{a}$ and $\mathrm{b}$ are the unit cell parameters and $\mathrm{M}$ is the molar mass of the clay mineral per unit cell. The calculation results in the specific surface areas of 756.7 and $750.2 \mathrm{~m}^{2} / \mathrm{g}$ for Na-MMT that contains smectite particles only and Na-SWy2, respectively, which are in parallel with the experimental ones (Table 1).

\subsection{Hydraulic conductivity}

The permanent hydro-mechanical regime is defined by the leachate production and strain equilibrium (Jullien et al., 2002). The solute intake shown as a function of time in Fig. 2 
displays a constant flow for both experiments after about $50 \mathrm{~h}$, which landmarks the end of the transient hydraulic state. The hydraulic conductivity, $\mathrm{k}$, was then calculated from the Darcy’s law, using the expression elaborated for a saturated medium (Domenico and Schwartz, 1990): $\mathrm{k}=\mathrm{Q}$ / i S, where $\mathrm{Q}$ is the measured volumetric flow rate $\left(\mathrm{m}^{3} / \mathrm{s}\right)$ at the steady state, $\mathrm{i}$ is the hydraulic gradient and $\mathrm{S}$ is the cross-sectional area of the œdometer $\left(\mathrm{m}^{2}\right)$. The hydraulic conductivity k of the compacted synthetic Na-MMT smectite percolated with water $\left(3.810^{-12} \mathrm{~m} / \mathrm{s}\right)$ is slightly higher than the value obtained for the natural Na-SWy2 smectite $\left(0.910^{-12} \mathrm{~m} / \mathrm{s}\right)$. These results are in the same magnitude with the permeability $(\mathrm{k}=$ $1.110^{-12} \mathrm{~m} / \mathrm{s}$ ) of Fo-Ca, a bentonite sample compacted and soaked with water under the same conditions (Jullien et al., 2002).

\subsection{Hydration properties}

\subsection{Macroscopic swelling}

The axial swelling strain, $\varepsilon_{1}$, deduced from the measured axial displacements of the piston, is illustrated as a function of time for both percolation experiments with water (Fig. 3). For Na-SWy2, the mechanical permanent regime, corresponding to the asymptotic $\varepsilon_{1}$ value, is obtained after 10 days of percolation. The natural Na-SWy2 sample shows a high swelling strain at equilibrium with a value of $37 \%$, whereas the Na-MMT synthetic smectite sample has a very low macroscopic swelling strain, around $1 \%$. Moreover, we have tested the swelling ability of both Na-MMT and Na-SWy2, without any mechanical constraint. For this purpose, $200 \mathrm{mg}$ of powdered clay sample was gradually added to $10 \mathrm{~mL}$ of deionised water in a cylinder and the swelling was recorded after $24 \mathrm{~h}$ of contact time. In the presence of water, the natural Na-SWy2 smectite was transformed into a gelling phase and swollen with a volume gain of $8.5 \mathrm{~mL}$, whereas the synthetic Na-MMT sample remained unchanged. 


\subsubsection{Crystalline swelling}

X-ray diffraction technique has been used to determine the mineralogy of both NaMMT and Na-SWy2 samples, as well as to quantify the crystalline swelling by measuring the $\mathrm{d}(001)$ basal spacing. Under the same conditions of adsorption $\left(\mathrm{T}=303 \mathrm{~K}\right.$ and $\left.\mathrm{P} / \mathrm{P}_{0}=0.5\right)$, the (001) reflection came at $1.21 \mathrm{~nm}$ for Na-SWy2, but shifted at $1.55 \mathrm{~nm}$ for Na-MMT (Fig. 1), revealing that the synthetic Na-MMT smectite has a higher hydration state (double water layer) than the natural Na-SWy2 smectite (single water layer). The variation of the $\mathrm{d}(001)$ basal spacing as a function of the relative water partial pressure is presented in Fig. 4. At the lowest pressure $\left(\mathrm{P} / \mathrm{P}_{0}=0.05\right)$, the basal distance of Na-MMT reaches $1.1 \mathrm{~nm}$ which is higher than a dry situation of $1.0 \mathrm{~nm}$ implying that the crystalline swelling has already begun with a partial intercalation of the first water layer. Similar trends were followed by the natural NaSWy2 and the synthetic Na-MMT samples up to a pressure of 0.44 in the presence of single water layer. At 0.53, Na-SWy2 still retains single water layer, whereas the XRD pattern of Na-MMT reveals two distinct reflections at 1.3 and $1.5 \mathrm{~nm}$, corresponding to the coexistence of particles associated with single and double water layers. The same feature is obtained at the highest water pressure $\left(\mathrm{P} / \mathrm{P}_{0}=0.98\right)$, where the appearance of a new reflection at $1.9 \mathrm{~nm}$ points out that the crystalline swelling of Na-MMT has reached three water layers whereas the NaSWy2 particles only contain two water layers in the interlayer spacing. Na-MMT hydrates more than Na-SWy2 at lower water partial pressures. Whatever the relative humidity is, the (001) reflection of Na-MMT is always finer than Na-SWy2, as clearly shown on Fig. 1 for $\mathrm{P} / \mathrm{P}_{0}$ equal to 0.5 , or on Fig. 4 at 0.65 where the (001) distance at $1.35 \mathrm{~nm}$ for Na-SWy2 in fact corresponds to an average value between single and double water layer species. These results outline that the synthetic particles have a better organization than the natural ones. 
Water sorption isotherms for the synthetic Na-MMT montmorillonite (Fig. 5) display irregular shapes characteristic of swelling material which suggest complex water adsorption mechanisms (Cases et al., 1992). More precisely, the sorption isotherms of Na-MMT exemplify those typical for Na-exchanged montmorillonites (Cases et al., 1992; Bérend et al., 1995). At relatively low pressures $\left(\mathrm{P} / \mathrm{P}_{0}<0.2\right)$, adsorption of water occurs only on external surfaces which is followed by a sharp increase at $\mathrm{P} / \mathrm{P}_{0}>0.25$, the behaviour ascribed to the adsorption of water molecules in the interlamellar spacing. The application of the BET equation using a water cross-sectional area of $0.148 \mathrm{~nm}^{2}$ yields an energetic constant of the BET theory equal to 14 and a total specific surface area of $149 \mathrm{~m}^{2} / \mathrm{g}$ which is significantly higher than the value $\left(106 \mathrm{~m}^{2} / \mathrm{g}\right)$ obtained for Na-SWy2. Therefore the synthetic Na-MMT particles, owing to a greater external surface area, become accessible by more water molecules during the adsorption.

\subsection{Geometric and energetic surface properties}

\subsubsection{Nitrogen adsorption-desorption at $77 \mathrm{~K}$}

Nitrogen adsorption-desorption experiments are used to obtain further information on the specific surface area of dried particles, resulting of the stacking of several individual sheets, and also on pore size distribution of the synthetic Na-MMT sample. Adsorptiondesorption curves of Na-MMT and Na-SWy2 (Fig. 6) reveal the classical features observed

for swelling clay minerals having both microporosity and mesoporosity (Michot and Villiéras, 2002; Neaman et al., 2003; Marrochi et al., 2005; Perronnet et al., 2007). The adsorption isotherms of Na-MMT and Na-SWy2 are of type II with a hysteresis loop, originating from the capillary condensation of liquid nitrogen in mesopores (Sing et al., 1985). The low pressure region $\left(\mathrm{P} / \mathrm{P}_{0}<0.42\right)$ represents to the filling of micropores, the completion of the 
first monolayer on external particle faces which is followed by the multilayer adsorption. In the relatively high pressure region $\left(\mathrm{P} / \mathrm{P}_{0}>0.42\right)$, the shape of the hysteresis loop corresponding to the filling of the mesoporosity is typical of type H3 with any limiting adsorption taking place at high $\mathrm{P} / \mathrm{P}_{0}$, which has been observed with aggregates of plate-like particles giving rise to slit-shaped pores (Sing et al., 1985). Moreover, the vertical closure of the hysteresis loop around 0.44 in $\mathrm{P} / \mathrm{P}_{0}$ is generally observed for such materials as a typical feature of closed mesoporosity inside clay aggregates (Neaman et al., 2003). The adsorptiondesorption isotherms of Na-MMT demonstrate a very important hysteresis loop $\left(\mathrm{P} / \mathrm{P}_{0}>0.7\right)$, which points out a well-calibrated mesoporosity. The BET and t-plot calculations applied to the nitrogen adsorption isotherm of Na-MMT give a total specific area of 87.1 and $92.8 \mathrm{~m} / \mathrm{g}$, respectively; which are twice higher than those of Na-SWy2 (Table 2). BET specific surface areas are slightly smaller than those derived from t-plot calculation, which is in agreement with the fact that both samples are slightly microporous. The specific surface areas of micropores are equivalent in both cases, with the values of 17 and $21 \mathrm{~m}^{2} / \mathrm{g}$, respectively, which show that the microporosity is not quantitatively important in comparison to activated carbon or zeolites. However, Na-MMT is characterized by a higher mesoporosity, as this synthetic smectite develops an external specific surface area three times higher than the natural Na-SWy2 smectite. To confirm this proposal, pore size distributions (PSD) were calculated according to the BJH method by applying the parallel pore model (Barrett et al., 1951) for Na-MMT and Na-SWy2 (Fig. 7). Calculated PSD from the adsorption and desorption parts, which correspond to true and access PSD values, respectively (Neaman et al., 2003) signify that pore access is linked to mesopores smaller than $2.6 \mathrm{~nm}$ in both cases, but the synthetic Na-MMT sample includes an additional access size around $5.1 \mathrm{~nm}$. This difference may be explained by referring to the mesoporosity. Indeed, particle arrangement and PSD of swelling clay minerals depend on sample preparation, such as dehydration 
conditions (Michot and Villiéras, 2002). The pore size distribution of the synthetic Na-MMT montmorillonite is found to be similar to the previously obtained result for the natural Prassa smectite (Perronnet et al., 2007).

When the specific surface area is known, the mean number of layers (n) contained by a clay particle may be determined by the following equation (Cases et al., 1992):

$\mathrm{S}\left(\mathrm{m}^{2} / \mathrm{g}\right)=801.3 / \mathrm{n}+5.13$

In dry condition, the particles of the synthetic Na-MMT smectite are made up of 9 to 10 layers, which is less than the average number of 20 layers found for the natural Na-SWy2 smectite. Our results are in agreement with those of Lantenois et al. (2007) who have also obtained 9 layers constituting a particle of a synthetic montmorillonite by using X-ray data and the Scherrer equation (Moore and Reynolds, 1997).

\subsubsection{Low-pressure argon adsorption at $77 \mathrm{~K}$}

The experimental argon derivative isotherm of Na-MMT is displayed in Fig. 8, together with the four local isotherms, using the DIS procedure. Fitting parameters are given in Table3. The curves of the synthetic Na-MMT smectite resemble classical adsorption energy distributions of natural phyllosilicates (Villiéras et al., 1992, 1997a, 1997b; Bardot et al., 1998; Michot \& Villiéras, 2002; Tournassat et al., 2003; Perronnet et al., 2007), with a main peak located at -4.11 (domain 2), assigned to the adsorption on basal surfaces, and a shoulder centred at -7.05 (domain 3), corresponding to the adsorption on lateral (or edge) surfaces. As classically obtained with argon measurements, the broad high-energy peak centred at -10.66 (domain 4), is also assigned to edge surfaces of the particles, whereas the low-energy contribution located at -2.27 (domain 1 ) is due to the adsorption on basal surfaces. The same DIS procedure applied on experimental Ar low-pressure adsorption was used for the Na-SWy2 sample (Fig. 8b), whose adjusted parameters are presented in Table 3, as well 
as those previously obtained for other natural Na-exchanged smectites, MX-80 (Tournassat et al., 2003) and Prassa (Perronnet et al., 2007), respectively. Five local isotherms are necessary to model the experimental curves of Prassa with the presence of a higher energy adsorption site on edge faces (domain 5) at -12.80. The peak positions corresponding to domains 1 and 2 (basal faces) are quite lower for the synthetic Na-MMT montmorillonite in comparison with the natural samples. However, the situation is different for edge faces as adsorption energy for domain 4 increases in the order: Na-SWy2 $<$ Prassa $<$ MX-80 $<$ Na-MMT. These high-energy adsorption sites of the less important domain 4 (and also of 5 for Prassa) could be attributed to chemical variability or non-uniform morphology such as local defects, corners or ridges of particle surfaces (Perronnet et al., 2007). As the two low-energy peaks (domains 1 and 2) are assigned to the adsorption on basal faces, and the three high-energy peaks (domains 3, 4 and 5) to the adsorption on edge faces, the basal and lateral surface areas can be calculated separately (Table 4). The proportion of lateral surface is similar for Na-MMT, MX-80, and Prassa, with the total surface area values of $26.5 \%, 24.2 \%$, and $27 \%$, respectively, whereas Na-SWy2 is completely different with a majority of edge faces (54\%). Moreover, it may be pointed out that the synthetic Na-MMT smectite is characterized by basal and edge surface areas very close to those obtained for Prassa previously. In order to have more information on the geometric properties, mean characteristic length (l) and thickness (t) of the particles have been calculated from basal and lateral surface areas by assuming a simple square base, as proposed by Tournassat et al. (2003):

$$
l=4 / \rho \cdot S_{l} \quad \text { and } \quad t=2 / \rho \cdot S_{b}
$$

where $\rho$ is the density $\left(2.7 \mathrm{~g} / \mathrm{cm}^{3}\right)$ and $S_{\mathrm{l}}$ and $S_{b}$, are the lateral and basal surface areas, respectively. Calculations give a length of 65 and $58 \mathrm{~nm}$ for Na-MMT and Na-SWy2, respectively, but the thickness increases from 12 to $34 \mathrm{~nm}$ for these samples (Table 4). The smaller thickness of Na-MMT particles is likely to be responsible partly for the greater 
mesoporosity of this sample as derived from nitrogen adsorption/desorption experiments. Taken into account the theoretical thickness of one dry smectite unit layer $(0.95 \mathrm{~nm})$, the average number of 2:1 layers per stack under dry condition is around 12-13 for Na-MMT, which is almost in the same order with Prassa (11 layers), but much lower than those of MX80 and Na-SWy2 (29 and 36 layers per particle, respectively) (Table 4). The present results highlight textural similarities between Na-MMT and the Prassa smectite, resulting from the low-temperature alteration of a rhyolitic rock in Greece (Christidis, 2001). The latter clay mineral appears to be a better natural clay analogue for the synthetic Na-MMT montmorillonite than the Wyoming Na-SWy2 smectite which is a classical model used in the literature.

\section{Conclusions}

The hydrothermal synthesis of a pure dioctahedral smectite was performed successfully. The synthetic Na-MMT montmorillonite exhibits similar high cation exchange capacity and total ethylene glycol specific surface area which are comparable to the natural Na-exchanged Wyoming smectite. The synthetic montmorillonite is characterized by a better crystalline swelling but no macroscopic swelling is observed when exposed to water. The hydro-mechanical properties of smectites, such as hydraulic conductivity and macroscopic swelling, measured at a macroscopic scale, are obviously linked to the multi-scale organization of porosity and also to the geometric and energetic properties of surface particles. The interlayer position of some magnesium cations could contribute to the nonmacroscopic swelling of the synthetic Na-MMT montmorillonite, by preventing from the delamination of layers in the presence of water. However, the interlayer space of Na-MMT is mainly occupied by sodium cations, which may prevail for the swelling behaviour against magnesium. The particles of the synthetic Na-MMT smectite do not have sufficient length in 
contrast to the natural Na-SWy2 sample, in order to obtain a gel phase, and textural anisotropy has to be taken into account to reach the sol/gel transition. Our future work will focus on the investigation of the dependence of macroscopic swelling and sol/gel transition on particle size and exfoliation which will mainly be searched through laser granulometry and transmission electron microscopy.

\section{Acknowledgments}

The authors are grateful to Patrick Lecomte for the conception of the œdometer cell and Fabien Veillon for the technical assistance. The Editor and two anonymous reviewers are gratefully acknowledged for their useful comments and suggestions on the paper. The authors express their gratitudes to the French National Agency for Research (ANR) for the financial support. This publication is a contribution to the ANR-07-JCJC-0013-01 (Metalclay) project allocated to L. Le Forestier.

\section{References}

Ammann, L., Bergaya, F., Lagaly, G., 2005. Determination of the cation exchange capacity of clays with copper complexes revisited. Clay Minerals 40, 441-453.

Bardot, F., Villiéras, F., Michot, L.J., François, M., Gérard, G., Cases, J.M., 1998. High resolution gas adsorption study on illites permuted with various cations: assessment of surface energetic properties. Journal of Dispersion Science and Technology 19, 739759.

Barrett, E.P., Joyner, L.G., Halenda, P.H., 1951. The determination of pore volume and area distributions in porous substances. I. Computations from nitrogen isotherms. Journal of the American Chemical Society 73, 373-380. 
Bérend, I., Cases, J.M., François, M., Uriot, J.P., Michot, L.J., Masion, A., Thomas, F., 1995. Mechanism of adsorption and desorption of water vapour by homoionic montmorillonites: 2. The $\mathrm{Li}^{+}, \mathrm{Na}^{+}, \mathrm{K}^{+}, \mathrm{Rb}^{+}$, and $\mathrm{Cs}^{+}$-exchanged forms. Clays and Clay Minerals 43, 3, 324-336.

Brunauer, S., Emmet, P.H., Teller, E., 1938. Adsorption of gases in multimolecular layers. Journal of the American Chemical Society 60, 309-319.

Caglar, B., Afsin, B., Tabak, A., Eren, E., 2009. Characterization of the cation-exchanged bentonites by XRPD, ATR, DTA/TG analyses and BET measurement. Chemical Engineering Journal 149, 242-248.

Carrado, K.A., Thiyagarajan, P., Song, K., 1997. A study of organo-hectorite clay crystallization. Clay Minerals 32, 29-40.

Cases, J.M., Berend, I., Besson, G., François, M., Uriot, J.P., Poirier, J.E., 1992. Mechanism of adsorption and desorption of water vapor by homoionic montmorillonite: 1 . The sodium-exchanged form. Langmuir 8, 2730-2739.

Chipera, S.J., Bish, D.L., 2001. Baselines studies of the clay minerals society source clays: Powder X-ray diffraction analyses. Clays and Clay Minerals 49, 398-409.

Christidis, G., 2001. Formation and growth of smectites in bentonites: a case study from Kimolos Island, Aegean, Greece. Clays and Clay Minerals 49, 204-215.

De Boer, J.H., Lippens, B.C., Linsen, B.G., Broekhoff, J.C.P., Van Den Heuvel, A., Osinga, T.J., 1966. The t-curve of multimolecular $\mathrm{N}_{2}$ adsorption. Journal of Colloid and Interface Science 21, 405-414.

Decarreau, A., Petit, S., Martin, F., Farges, F., Vieillard, P., Joussein, E., 2008. Hydrothermal synthesis, between 75 and $150^{\circ} \mathrm{C}$, of high-charge, ferric nontronites. Clays and Clay Minerals 56, 322-337. 
Delevoye, L., Robert, J.L., Grandjean, J., 2003. ${ }^{23} \mathrm{Na} 2 \mathrm{D} 3 \mathrm{QMAS}$ NMR and ${ }^{29} \mathrm{Si},{ }^{27} \mathrm{Al}$ MAS NMR investigation of Laponite and synthetic saponites of variable interlayer charge. Clay Minerals 38, 63-69.

Domenico, P.A., Schwartz, F.W., 1990. Ground water movement. Chapter 3, in: Physical and Chemical Hydrogeology. Wiley, New York, pp. 56-57.

Duc, M., Thomas, F., Gaboriaud, F., 2006. Coupled chemical processes at clay/electrolyte interface: A batch titration study of Na-montmorillonite. Journal of Colloid and Interface Science 300, 616-625.

Eltantawy, I.M., Arnold, P.W., 1974. Ethylene glycol sorption by homoionic montmorillonites. Journal of Soil Science 25, 99-110.

Galan, E., 2006. Genesis of clay minerals. Chapter 14, in: Bergaya, F., Theng, B.K.G., Lagaly, G. (Eds.), Handbook of Clay Science. Elsevier, Amsterdam, pp. 1129-1162.

Hamilton, D.L., Henderson, C.M.B., 1968. The preparation of silicate compositions by a gelling method. Mineralogical Magazine 36, 832-838.

Harkins, W.D., Jura, G., 1944. Surface of solids. XIII. A vapor adsorption method for the determination of the area of a solid without the assumption of a molecular area, and the areas occupied by nitrogen and other molecules on the surface of a solid. Journal of the American Chemical Society 66, 1366-1373.

Helmy, A.K., Ferreiro, E.A., Bussetti, S.G., 1999. Surface area evaluation of montmorillonite. Journal of Colloid and Interface Science 210, 167-171.

Jullien, A., Lecomte, P., 2000. Dispositif perméamétrique à injecteur à pression contrôlée séparé. Brevet Français N00/07820.

Jullien, A., Proust, C., Le Forestier, L., Baillif, P., 2002. Hydro-chemio-mechanical coupling effects on permeability and swelling behaviour of a Ca smectite soaked by Cu solutions. Applied Clay Science 21, 143-153. 
Kloprogge, J.T., Van Der Eerden, A.M.J., Ben H. Jansen, J., Geus, J.W, Schuiling, R.D., 1993. Synthesis and paragenesis of Na-beidellite as a function of temperature, water pressure, and sodium activity. Clays and Clay Minerals 41, 423-430.

Laird, D.A., 2006. Influence of layer charge on swelling of smectites. Applied Clay Science 34, 74-87.

Lantenois, S., Nedellec, Y., Prélot, B., Zajac, J., Muller, F., Douillard, J.M., 2007. Thermodynamic assessment of the variation of the surface areas of two synthetic swelling clays during adsorption of water. Journal of Colloid and Interface Science 316, 1003-1011.

Lantenois, S., Muller, F., Bény, J.M., Mahiaoui, J., Champallier, R., 2008a. Hydrothermal synthesis of beidellites: characterization and study of the cis and trans-vacant character. Clays and Clay Minerals 56, 38-47.

Lantenois, S., Champallier, R., Bény, J.M., Muller, F., 2008b. Hydrothermal synthesis and characterization of dioctahedral smectites: A montmorillonites series. Applied Clay Science 38, 165-178.

Marrocchi, Y., Razafitianamaharavo, A., Michot, L., Marty, B., 2005. Low-pressure adsorption of $\mathrm{Ar}, \mathrm{Kr}$, and Xe on carbonaceous materials (kerogen and carbon blacks), ferrihydrite, and montmorillonite: Implications for the trapping of noble gases onto meteoritic matter. Geochimica et Cosmochimica Acta 69, 2419-2430.

Michot, L.J., François, M., Cases, J.M., 1990. Surface heterogeneity studied by a quasiequilibrium adsorption procedure. Langmuir 6, 637-643.

Michot, L.J., Villiéras, F., 2002. Assessment of surface energetic heterogeneity of synthetic Na-saponites. The role of layer charge. Clay Minerals 37, 39-57. 
Michot, L.J., Bihannic, I., Porsch, K., Maddi, S., Baravian, C., Mougel, J., Levitz, P., 2004. Phase diagrams of Wyoming Na-montmorillonite clay. Influence of particle anisotropy. Langmuir 20, 10829-10837.

Moore, D.M., Reynolds, R.C., 1997. X-Ray Diffraction and the Identification and Analysis of Clay Minerals, Oxford University Press, New York, pp. 87.

Murray, H.H, 1999. Applied clay mineralogy today and tomorrow. Clay Minerals 34, 39-49.

Neaman, A., Pelletier, M., Villiéras, F., 2003. The effects of exchanged cation, compression, heating and hydration on textural properties of bulk bentonite and its corresponding purified montmorillonite. Applied Clay Science 22, 153-168.

Perronnet, M., Villiéras, F., Jullien, M., Razafitianamaharavo, A., Raynal, J., Bonnin, D., 2007. Towards a link between the energetic heterogeneities of the edge faces of smectites and their stability in the context of metallic corrosion. Geochimica et Cosmochimica Acta 71, 1463-1479.

Pothier, C., Jullien, A., Proust, C., Lecomte, P., 2003. Etude des phénomènes de transfert de métaux lourds dans une smectite. Revue Française de Géotechnique 103, 33-42.

Reinholdt, M., Miehé-Brendlé, J., Delmotte, L., Le Dred, R., Tuilier, M.H., 2005. Synthesis and characterization of montmorillonite-type phyllosilicates in a fluoride medium. Clay Minerals 40, 177-189.

Sing, K.S.W., Everett, D.H., Haul, R.A.W., Moscou, L., Pierotti, R.A., Rouquérol, J., Siemieniewska, T., 1985. Reporting physisorption data for gas/solid systems with special reference to the determination of surface area and porosity. Pure \& Applied Chemistry 57, 603-619.

Spagnuolo, M., Martinez, C.E., Jacobson, A.R., Baveye, P., McBride, M.B., Newton, J., 2004. Coprecipitation of trace metal ions during the synthesis of hectorite. Applied Clay Science 27, 129-140. 
Tournassat, C., Neaman, A., Villiéras, F., Bosbach, D., Charlet, L., 2003. Nanomorphology of montmorillonites particles: Estimation of the clay edge sorption site density by lowpressure gas adsorption and AFM observations. American Mineralogist 88, 1989-1995.

Villiéras, F., Cases, J.M., François, M., Michot, L.J., Thomas, F., 1992. Texture and surface energetic heterogeneity of solids from modeling of low pressure gas adsorption isotherms. Langmuir 8, 1789-1795.

Villiéras, F., Michot, L.J., Cases, J.M., Bérend, I., Bardot, F., François, M., Gérard, G., Yvon, J., 1997a. Static and dynamic studies of the energetic surface heterogeneity of clay minerals, in: Rudzinski, W., Steele, W.A., Zgrablich, G. (Eds.), Equilibria and Dynamics of Gas Adsorption on Heterogeneous Solid Surfaces, Studies in Surface Science and Catalysis. Elsevier Science Publishers B. V., Amsterdam, 104, pp. 573-623. Villiéras, F., Michot, L.J., Bardot, F., Cases, J.M., François, M., Rudzinski, W., 1997b. An improved derivative isotherm summation method to study surface heterogeneity of clay minerals. Langmuir 13, 1104-1117. 


\section{Table 1}

Relevant features of the synthetic montmorillonite (Na-MMT) and the Na-exchanged Wyoming smectite (Na-SWy2).

\begin{tabular}{llll}
\hline & Structural formula & $\begin{array}{l}\text { CEC (meq/100g } \\
\text { of calcined clay) }\end{array}$ & $\begin{array}{l}\mathrm{SSA}^{\mathrm{d}} \\
\left(\mathrm{m}^{2} / \mathrm{g}\right)\end{array}$ \\
\hline Na-MMT & $\left(\mathrm{Na}_{0.68} \mathrm{Mg}_{0.03}\right)\left(\mathrm{Al}_{3.35} \mathrm{Mg}_{0.65}\right)\left(\mathrm{Si}_{7.91} \mathrm{Al}_{0.09}\right) \mathrm{O}_{20}(\mathrm{OH})_{4}{ }^{\mathrm{a}}$ & $83.0 \pm 0.3^{\mathrm{c}}$ & 763.8 \\
\hline Na-SWy2 & $\mathrm{Na}_{0.68}\left(\mathrm{Al}_{3.06} \mathrm{Fe}^{\mathrm{IIII}}{ }_{0.42} \mathrm{Mg}_{0.58}\right)\left(\mathrm{Si}_{7.90} \mathrm{Al}_{0.10}\right) \mathrm{O}_{20}(\mathrm{OH})_{4}{ }^{\mathrm{b}}$ & $85.0 \pm 2.7^{\mathrm{c}}$ & 736.8 \\
\hline
\end{tabular}

${ }^{\mathrm{a}}$ From ICP-OES and electron microprobe analyses of the solid clay, and AAS analyses of the supernatant after exchange with copper complex

${ }^{\mathrm{b}}$ From ICP-OES and electron microprobe analyses

${ }^{\mathrm{c}}$ Measured by colorimetry and AAS after exchange with copper complex

${ }^{\mathrm{d}}$ Specific surface area measured by adsorption of ethylene glycol. 


\section{Table 2}

Numerical results derived from the BET and t-plot methods of the $\mathrm{N}_{2}$ adsorption-desorption isotherms, and from the DIS method used for Ar adsorption. Previous data obtained for natural Na-exchanged smectites are given for comparison with the synthetic Na-MMT sample.

\begin{tabular}{|c|c|c|c|c|c|c|c|}
\hline & BET & & & t-plot & & & DIS \\
\hline & $\begin{array}{l}\mathrm{V}_{\mathrm{m}}^{\mathrm{a}} \\
\left(\mathrm{cm}^{3} / \mathrm{g}\right)\end{array}$ & $\mathrm{C}^{\mathrm{b}}$ & $\begin{array}{l}\mathrm{S}_{\text {tot }}^{\mathrm{c}} \\
\left(\mathrm{m}^{2} / \mathrm{g}\right)\end{array}$ & $\begin{array}{l}\mathrm{S}_{\mu \text { pores }} \mathrm{d} \\
\left(\mathrm{m}^{2} / \mathrm{g}\right)\end{array}$ & $\begin{array}{l}S_{\text {ext }}^{e} \\
\left(\mathrm{~m}^{2} / \mathrm{g}\right)\end{array}$ & $\begin{array}{l}\mathrm{S}_{\mathrm{tot}} \\
\left(\mathrm{m}^{2} / \mathrm{g}\right)\end{array}$ & $\begin{array}{l}\mathrm{S}_{\mathrm{Ar}}^{\mathrm{f}} \\
\left(\mathrm{m}^{2} / \mathrm{g}\right)\end{array}$ \\
\hline Na-MMT & 19.93 & 451 & 87.1 & 16.7 & 74.6 & 92.8 & 85.6 \\
\hline Na-SWy2 & 10.39 & 685 & 45.4 & 20.6 & 28.5 & 49.1 & 47.2 \\
\hline \multicolumn{8}{|c|}{${ }^{\mathrm{a}}$ Monolayer volume } \\
\hline \multicolumn{8}{|c|}{ b BET energy constant } \\
\hline \multicolumn{8}{|c|}{${ }^{\mathrm{c}}$ Total specific area $\left( \pm 4 \mathrm{~m}^{2} / \mathrm{g}\right)$} \\
\hline \multicolumn{8}{|c|}{${ }^{\mathrm{d}}$ Equivalent specific surface area of micropores ( $\left.\pm 20 \%\right)$} \\
\hline \multicolumn{8}{|c|}{${ }^{\mathrm{e}}$ External specific surface area $\left(=\mathrm{S}_{\text {tot }}-\mathrm{S}_{\mu \mathrm{pores}}, \pm 20 \%\right)$} \\
\hline
\end{tabular}




\section{Table 3}

Parameters adjusted to the experimental Ar derivative isotherm of Na-MMT and Na-SWy2 presented in Fig. 8, then compared to those of other natural Na-exchanged samples: the MX80 bentonite (Tournassat et al., 2003), and the Prassa smectite (Perronnet et al., 2007).

\begin{tabular}{|c|c|c|c|c|c|c|c|c|}
\hline \multicolumn{3}{|l|}{ Sample } & \multirow{2}{*}{$\begin{array}{l}\text { Domain } 1 \\
-2.27\end{array}$} & \multirow{2}{*}{$\begin{array}{l}\text { Domain } \\
2 \\
-4.11\end{array}$} & \multirow{2}{*}{$\begin{array}{l}\text { Domain } \\
3 \\
-7.05\end{array}$} & \multirow{2}{*}{$\begin{array}{l}\text { Domain } \\
4 \\
-10.66\end{array}$} & \multirow{2}{*}{$\begin{array}{l}\text { Domain } \\
5\end{array}$} & \multirow[t]{2}{*}{ Total } \\
\hline & $\begin{array}{l}\text { Peak } \\
\text { position }\end{array}$ & $\ln \mathrm{P} / \mathrm{P}_{0}$ & & & & & & \\
\hline \multirow{3}{*}{$\begin{array}{l}\mathrm{Na}- \\
\mathrm{MMT}\end{array}$} & $\mathrm{V}_{\text {monolayer }}$ & $\left(\mathrm{cm}^{3} / \mathrm{g}\right)$ & 4.18 & 12.76 & 4.51 & 1.62 & & \\
\hline & $\omega$ & $(\mathrm{kT})$ & 0.0 & 1.4 & 0.7 & -0.2 & & \\
\hline & $\mathrm{SSA}^{\mathrm{a}}$ & $\left(\mathrm{m}^{2} / \mathrm{g}\right)$ & 15.5 & 47.3 & 16.7 & 6.0 & & 85.5 \\
\hline \multirow{2}{*}{$\begin{array}{l}\text { Na- } \\
\text { SWy2 }\end{array}$} & $\begin{array}{l}\text { Peak } \\
\text { position }\end{array}$ & $\ln \mathrm{P} / \mathrm{P}_{0}$ & -2.73 & -4.38 & -7.05 & -9.63 & & \\
\hline & SSA & $\left(\mathrm{m}^{2} / \mathrm{g}\right)$ & 2.6 & 19.2 & 20.6 & 4.8 & & 47.2 \\
\hline \multirow[t]{2}{*}{$\mathrm{MX}-80^{\mathrm{b}}$} & $\begin{array}{l}\text { Peak } \\
\text { position }\end{array}$ & $\ln \mathrm{P} / \mathrm{P}_{0}$ & -2.52 & -4.14 & -7.05 & -10.29 & & \\
\hline & SSA & $\left(\mathrm{m}^{2} / \mathrm{g}\right)$ & 2.0 & 24.6 & 5.6 & 2.9 & & 35.1 \\
\hline \multirow[t]{2}{*}{ Prassa $^{c}$} & $\begin{array}{l}\text { Peak } \\
\text { position }\end{array}$ & $\ln \mathrm{P} / \mathrm{P}_{0}$ & -2.50 & -4.60 & -6.60 & -10.20 & -12.80 & \\
\hline & SSA & $\left(\mathrm{m}^{2} / \mathrm{g}\right)$ & 18.9 & 48.6 & 20.3 & 2.9 & 1.8 & 92.5 \\
\hline
\end{tabular}

${ }^{\mathrm{a}}$ Specific surface area

${ }^{\mathrm{b}}$ Data from Tournassat et al., 2003

${ }^{\mathrm{c}}$ Data from Perronnet et al., 2007 


\section{Table 4}

Geometrical characteristics of the dry particles of the synthetic Na-MMT sample compared with three natural Na-exchanged smectites, Na-SWy2, MX-80 and Prassa, respectively.

\begin{tabular}{lllll}
\hline & Na-MMT & Na-SWy2 & MX-80 & Prassa $^{\mathrm{b}}$ \\
\hline Basal surface area $\mathrm{S}_{\mathrm{b}}\left(\mathrm{m}^{2} / \mathrm{g}\right)$ & 62.8 & 21.7 & 26.6 & 67.5 \\
\hline Lateral surface area $\mathrm{S}_{\mathrm{l}}\left(\mathrm{m}^{2} / \mathrm{g}\right)$ & 22.7 & 25.4 & 8.5 & 25 \\
\hline Length l (nm) & 65 & 58 & 174.3 & 59 \\
\hline Thickness t (nm) & 12 & 34 & 27.8 & 11 \\
\hline $\begin{array}{l}\text { Layers per particle }(0.95 \mathrm{~nm} / \text { layer in dry } \\
\text { conditions) }\end{array}$ & $12-13$ & 36 & 29 & 11 \\
\hline
\end{tabular}

${ }^{\mathrm{a}}$ Data from Tournassat et al., 2003

${ }^{\mathrm{b}}$ Data from Perronnet et al., 2007 


\section{Figure captions}

Fig. 1. X-ray diffraction patterns of Na-MMT and Na-SWy2 samples, performed at $303 \mathrm{~K}$ and under a relative humidity of $50 \%\left(\mathrm{P} / \mathrm{P}_{0}=0.5\right)$. The $(00 /)$ reflections and the $(02.11)$, (20.13) and (06.33) reflections of smectite are labelled. Q indicates the presence of quartz in Na-SWy2 sample.

Fig. 2. Solute intake during percolation experiments of water in Na-MMT and Na-SWy2, respectively.

Fig. 3. Evolution of swelling strain during percolation experiments of water in Na-MMT and Na-SWy2, respectively.

Fig. 4. Evolution of the basal distance $\mathrm{d}(001)$ as a function of the relative water partial pressure $\mathrm{P} / \mathrm{P}_{0}$. Lines are guides for the eyes.

Fig. 5. Water adsorption-desorption isotherms obtained at $303 \mathrm{~K}$ for (a) the synthetic NaMMT and (b) the natural Na-SWy2 samples.

Fig. 6. Adsorption-desorption isotherms of nitrogen obtained at 77K for (a) the synthetic NaMMT and (b) the natural Na-SWy2 samples.

Fig. 7. Pore size distribution (PSD), calculated from nitrogen adsorption-desorption isotherms presented in Fig. 6, for (a) Na-MMT and (b) Na-SWy2 samples. Solid line shows adsorption pore size distribution (true PSD); dotted line shows desorption pore size distribution (access PSD).

Fig. 8. Adsorption energy distributions (thin solid lines) derived from low-pressure argon adsorption at $77 \mathrm{~K}$ of (a) Na-MMT and (b) Na-SWy2 samples. Local isotherms used to model experimental curves (contribution of elementary surfaces, dotted lines), and sum of these contributions (thick solid lines). Fitting parameters are presented in Table 3. 
Fig. 1.

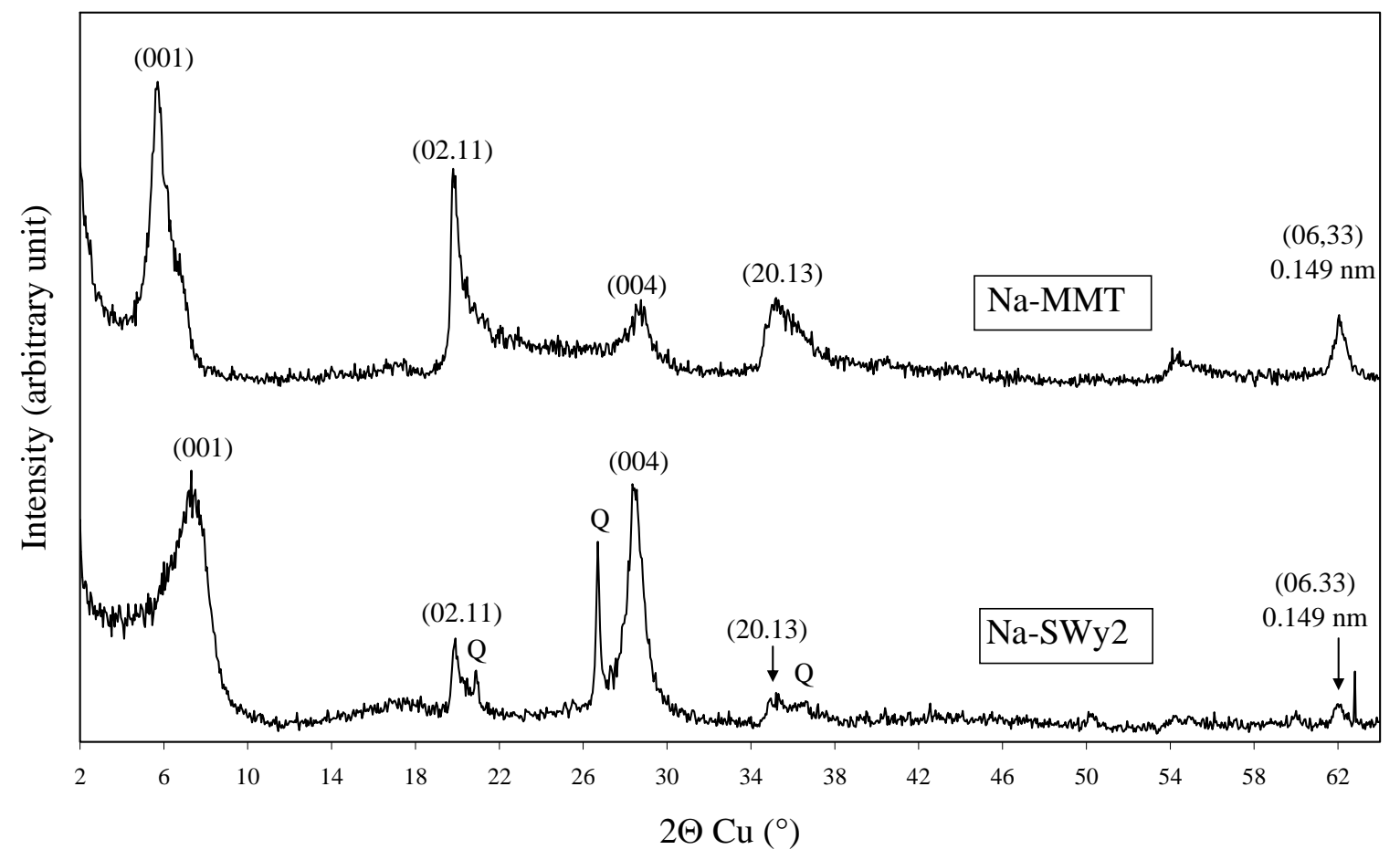


Fig. 2.

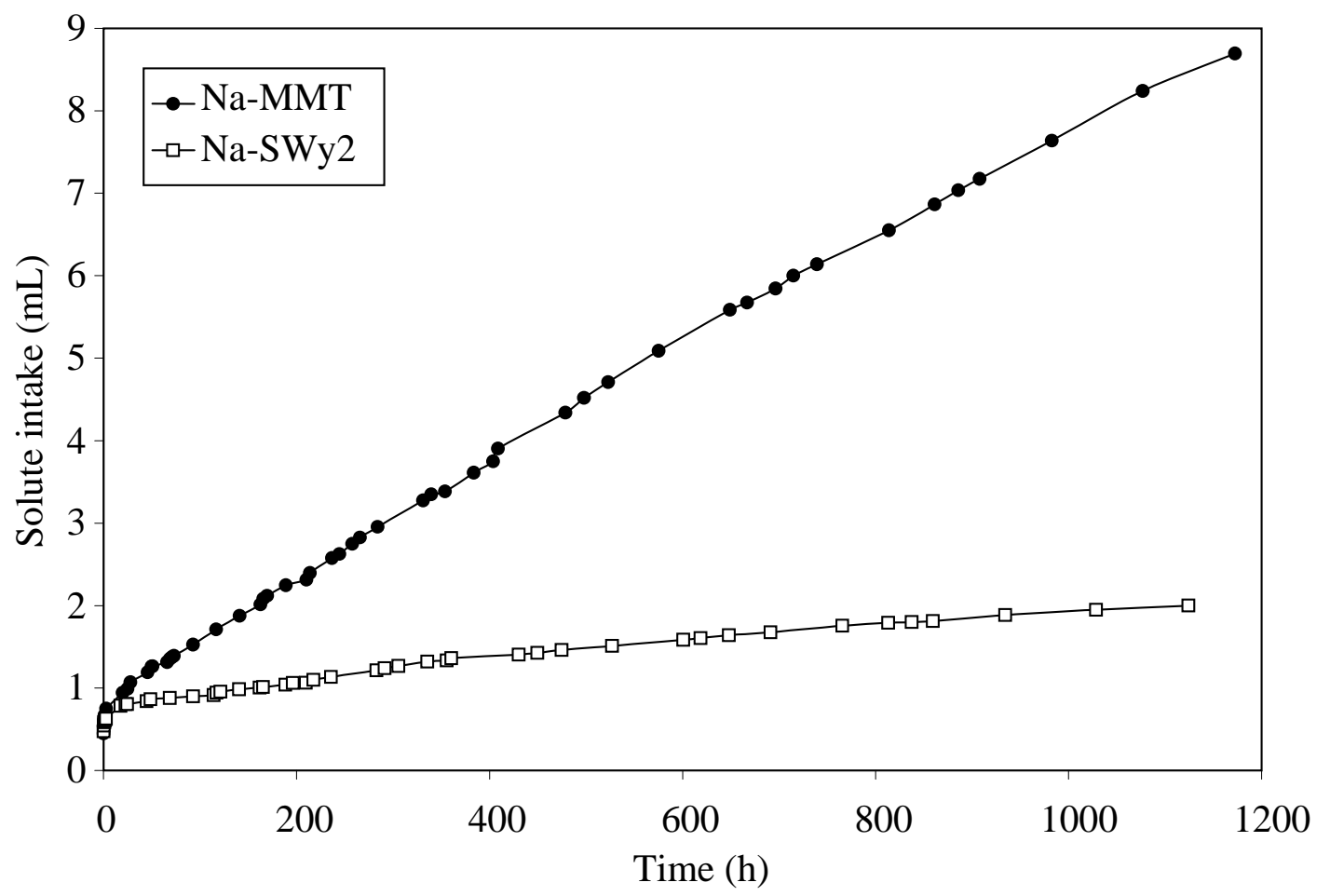


Fig. 3.

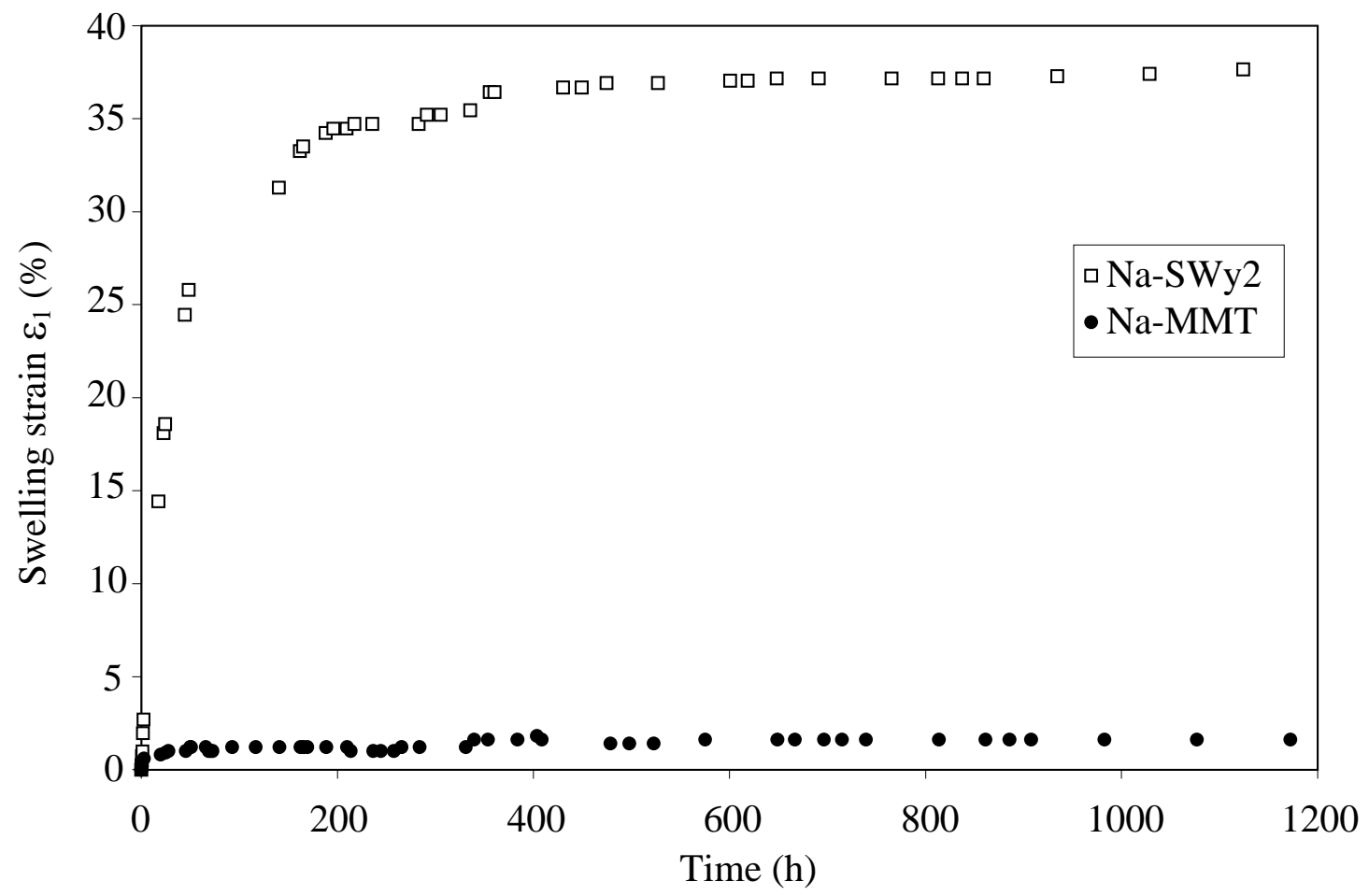


Fig. 4.

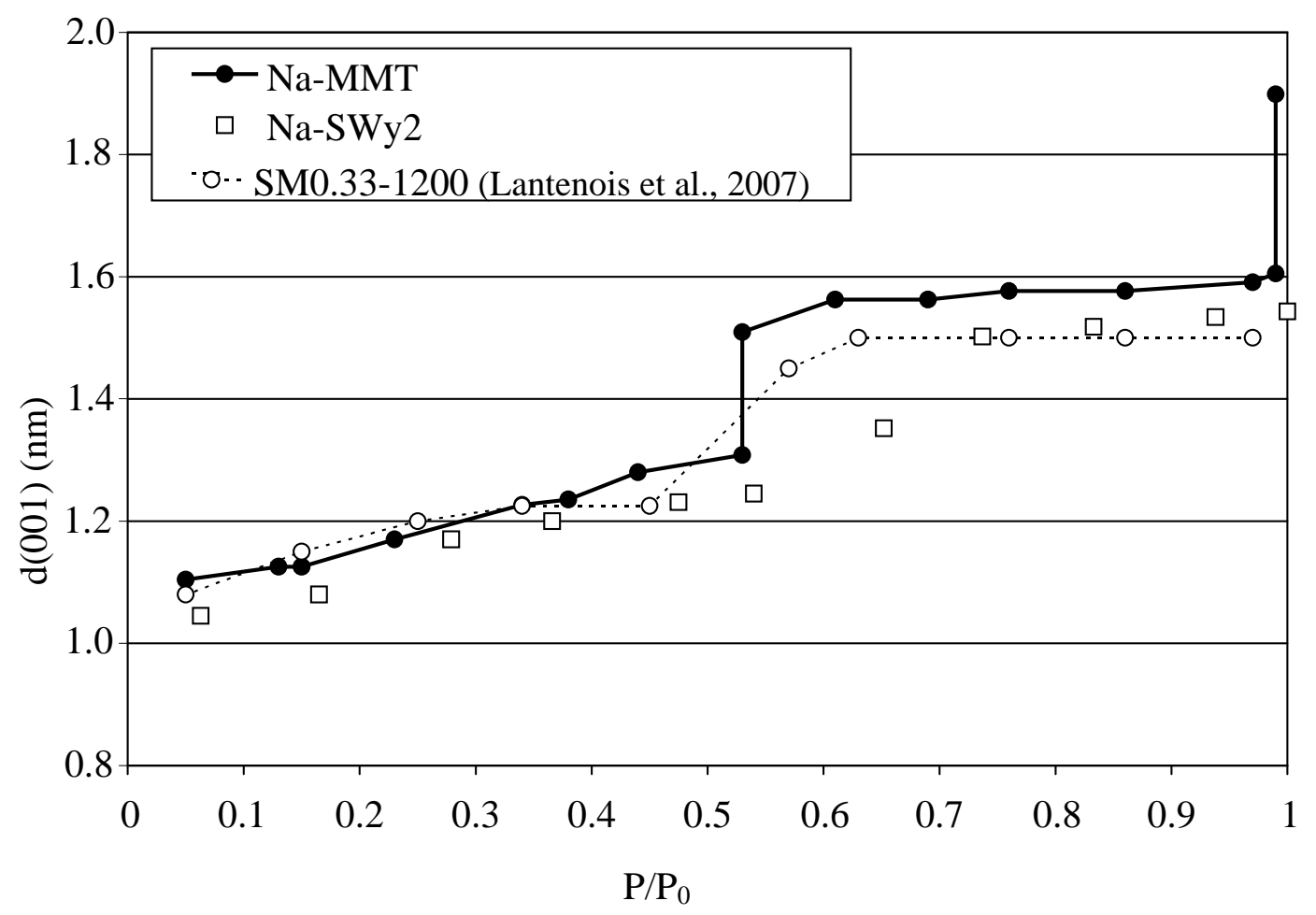


Fig. 5.
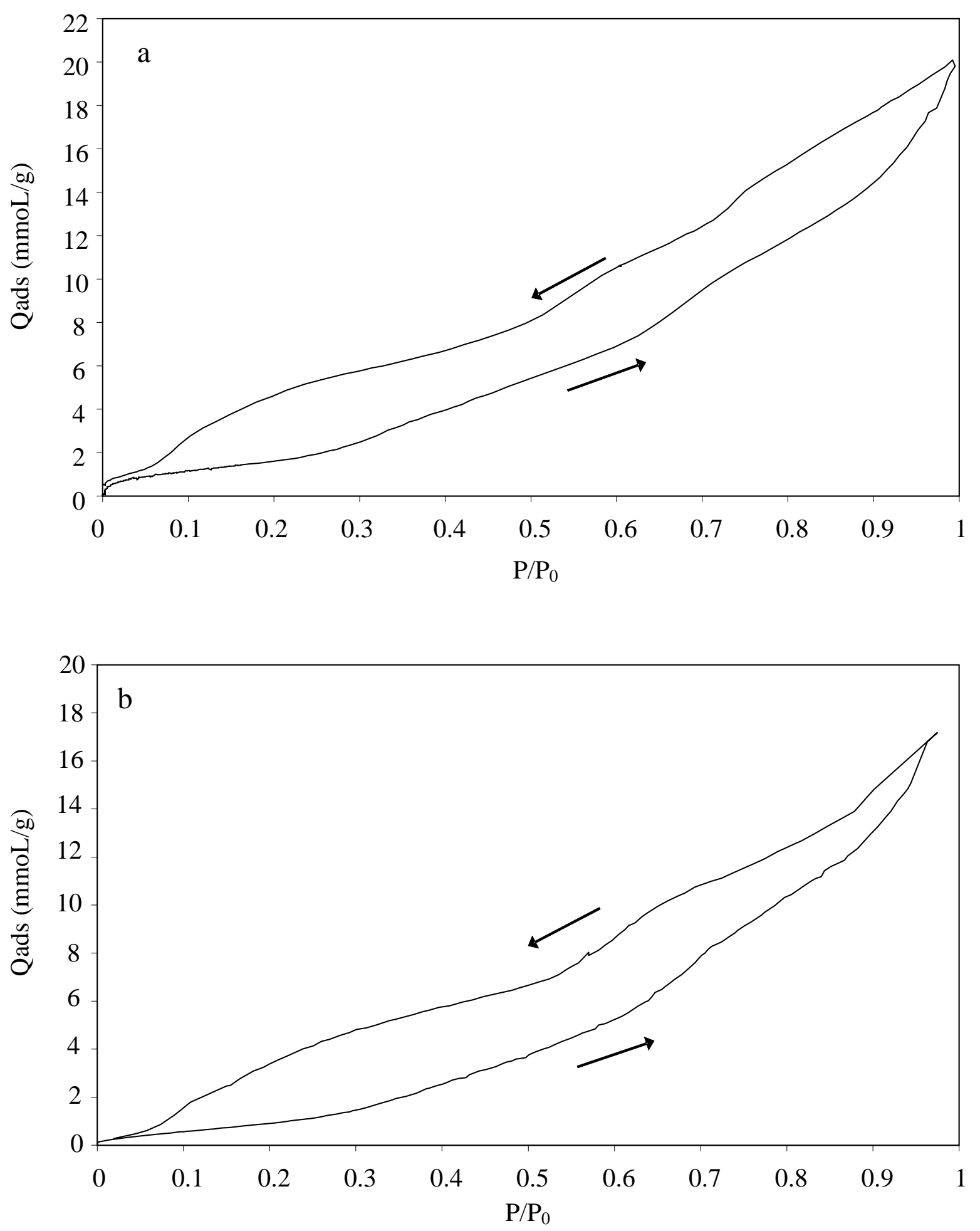
Fig. 6.
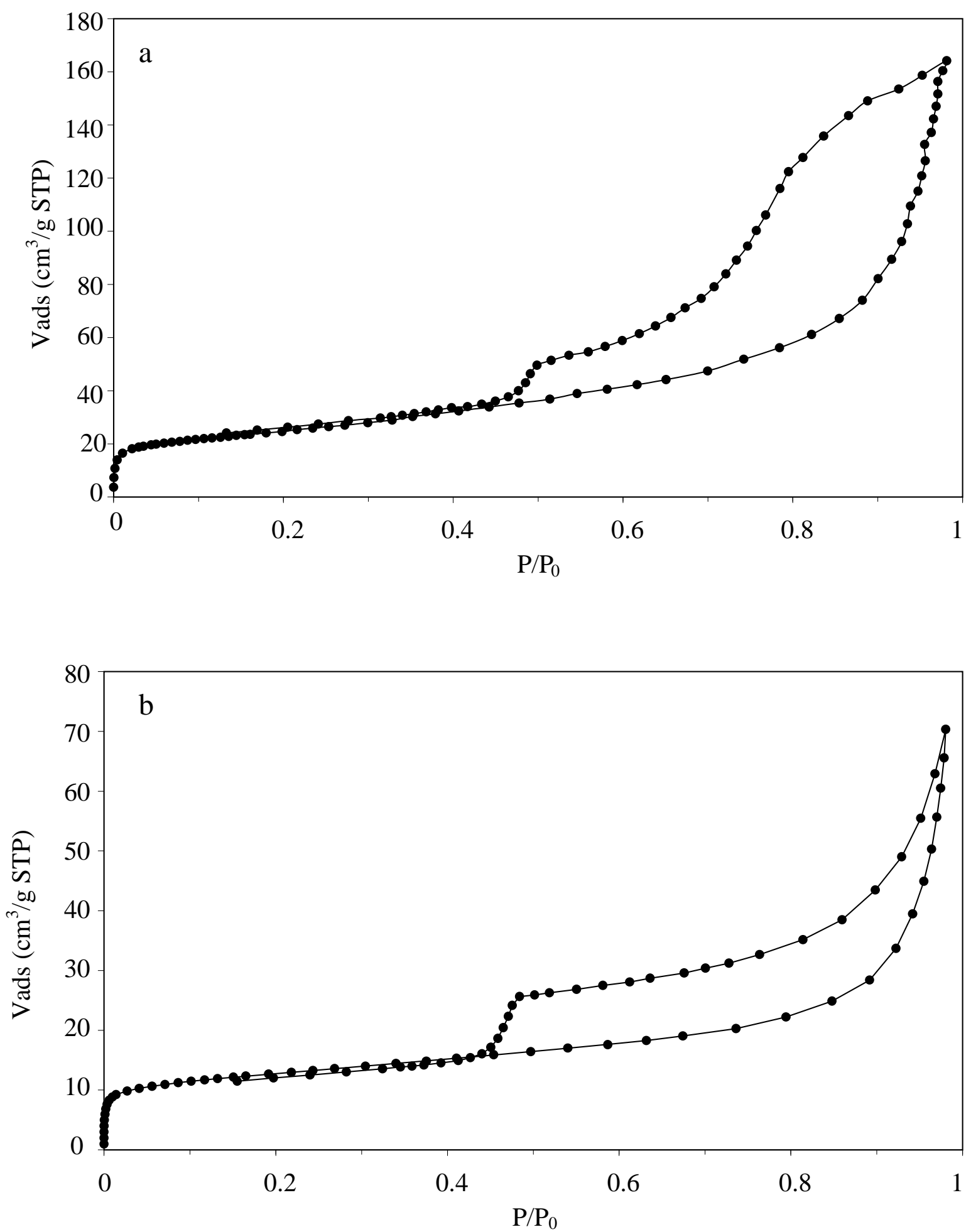
Fig. 7.
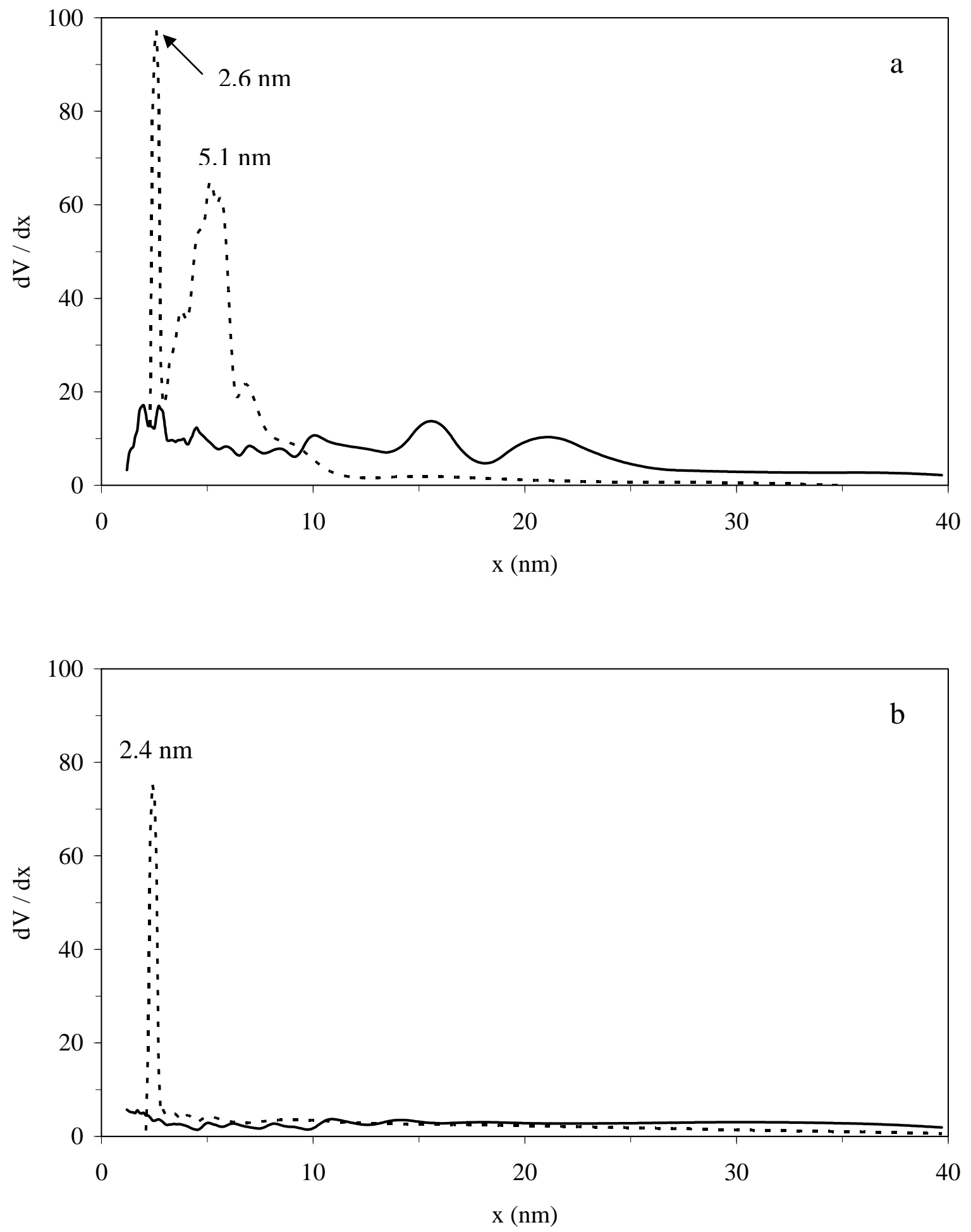
Fig. 8.
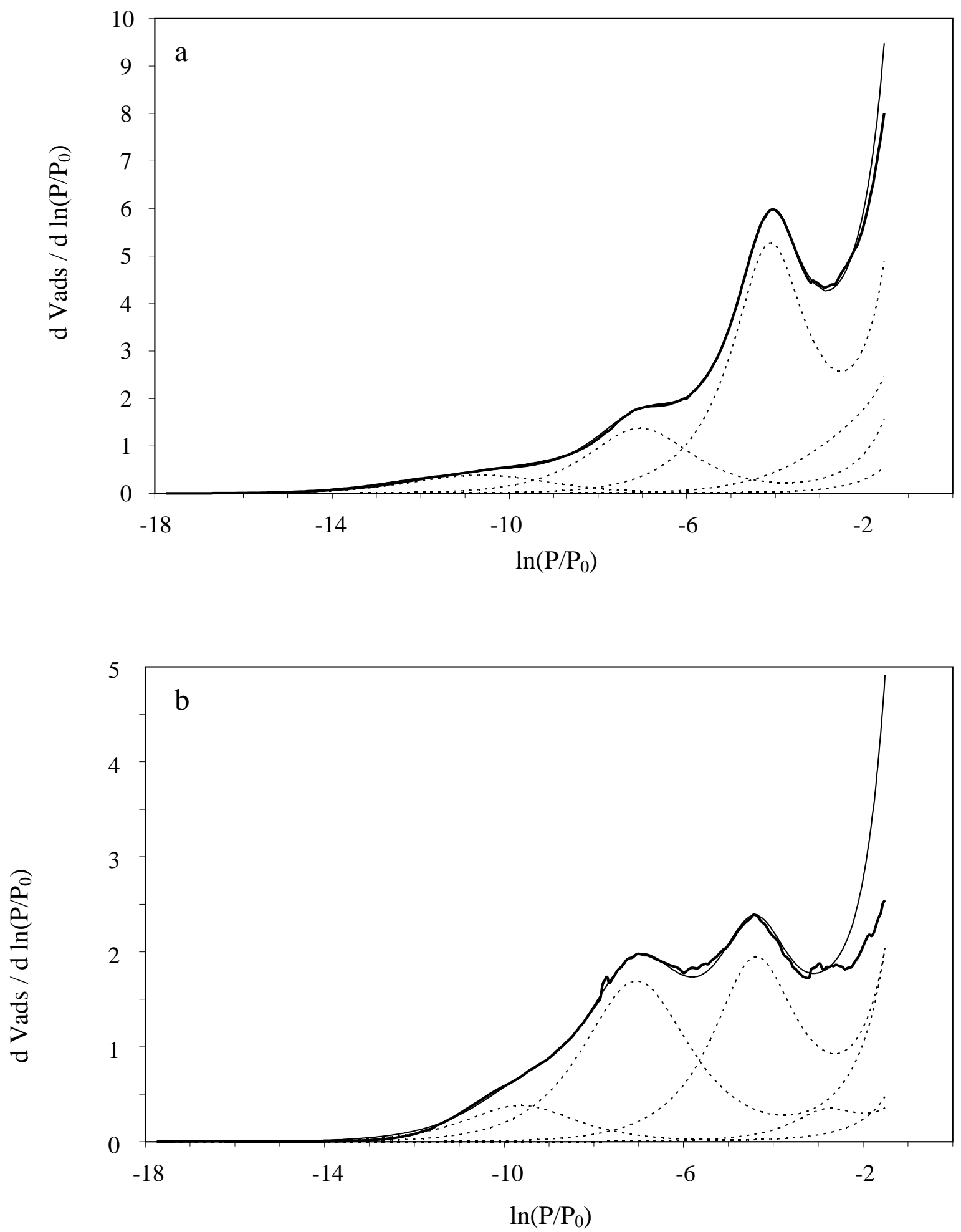